Situs Jurnal : $\underline{\text { http://ejournal.stiepancasetia.ac.id/index.php/jieb }}$

Jilid 7 Nomor 2 Juli 2021

Hal 169-178

\title{
PENERAPAN KEBIJAKAN OJK PEREKONOMIAN INDONESIA TERHADAP BANK SYARIAH MANDIRI PADA PANDEMI COVID-19
}

\author{
Mega Ambarwati, Muhammad Iqbal Fasa, Suharto
}

\begin{abstract}
Bank Syariah Mandiri is a form of financial institution that contributes greatly to the Indonesian economy. Coronavirus Disease-19 (COVID-19) creates similarities and comparisons in the affected economic sectors. This study aims to look at the effects of a pandemic on the Indonesian economy, the impact of the pandemic on BSM, and OKK policies during the pandemic. This research is a qualitative descriptive study. Researchers used literature review through reference books, scientific journals, online news sites, and other relevant literature. In the results of presenting the data, it is stated that the pandemic has an impact on the investment, trade, transportation and tourism sectors. The pandemic has also had a positive impact on the goals of independent Islamic bank digital transactions as an increase in the number of Mandiri Syariah Mobile customers, additional digital transactions, and additional online account creation.
\end{abstract}

Keywords: OJK, BSM, COVID-19 Pandemic, ECONOMY

\begin{abstract}
Abstrak: Bank Syariah Mandiri yaitu bentuk dengan lembaga keuangan yang berkontribusi besar pada perekonomian Indonesia. Coronavirus Disease-19 (COVID-19) menimbulkan persamaan dan perbandingan dalam sektor ekonomi yang terdampak. Studi ini bertujuan untuk mengetahui efek pandemi terhadap perekonomian Indonesia, dampak pandemi terhadap BSM, dan kebijakan ojk di masa pandemi. Penelitian ini merupakan penelitian deskriptif kualitatif. Peneliti menggunakan kajian studi pustaka melalui buku referensi, jurnal ilmiah, situs berita online, dan literatur lainnya yang relevan. Dalam hasil penyajian data menyatakan bahwa pandemi berdampak dalam sektor investasi, perdagangan, transportasi, dan pariwisata. Pandemi juga berdampak postif dalam tujuan transaksi digital bank syariah mandiri sebagai penambahan banyaknya nasabah Mandiri Syariah Mobile, penambahan transaksi digital, dan penambahan pembuatan rekening online.
\end{abstract}

Kata Kunci: OJK, BSM, Pandemi COVID-19, PEREKONOMIAN 


\section{Pendahuluan}

Corona Virus Desease 19 (Covid19) yaitu wabah yang sudah ditetapkan bagi Word Healt Organization (WHO) sejak permulaan tahun 2020 (WHO, 2020). Hal ini ditimbulkan mata rantai sebaran virus sudah menular ke banyak sekali belahan global dengan sangat cepat yang bermula di Kota Wuhan, Provinsi Hubei-China(Junusi, 2020; Sodikin, 2020). Di luar negara China, Covid-19 sudah menyebabkan 7000 fakta aktual dan 3000 orang sudah tewas (Dong et al, 2020). Indonesia adalah satu diantara negara yang terkena efek wabah Covid-19. Dari keterangan data statistik dalam bulan maret 2020 memperlihatkan banyaknya perkara menyatakan terkonfirmasi positif 1528 dan 114 tewas (Kementrian Kesehatan, 2020). Pengaruh Covid-19 tidak hanya ke sektor kesehatan, namun hampir ke seluruh sektor menyatakan perkiraan akan berlangsung lama. (Djalante et al. 2020)

Sistem perbankan pada Indonesia merupakan hal yang berdampak selain sektor kesehatan, tergolong perbankan syariah. sehingganya, BI (2020) menjalankan upaya berkurangnya risiko beserta menyerahkan dorongan pengaturan dalam rangka mengawasi kestabilan sistem perbankan berupa rangkaian relaksasi pembiayaan atau pengurangan dalam angsuran pembiayaan konsumen. Kebijakan Bank Sentral hendaklah mampu bergerak maju secara efektif untuk ikut andil mendorong sesuatu yang dicapai oleh perbankan syariah. Hal itu seuai dengan sesuatu pemeriksaan. (Riduwan and Wahyudi 2018) dan (Wahyudi, Mujibatun, and Riduwan 2019) yang menetapkan bahwa dorongan berkontribusi penting terhadap kemampuan perbankan syariah di Indonesia. (Hidayat et al. 2020) Menerangkan bahwa dalam situasi Covid 19 gelombang krisisnya berbeda, dimana menjadikan sesuatu yang baru ada tiga krisis besar, ialah krisis kesehatan, krisis ekonomi, dan krisis sosial.
Kasus Covid-19 di Indonesia

\begin{tabular}{|l|l|l|l|}
\hline Province & Cases & Recovery & Deaths \\
\hline Jakarta & 4.092 & 440 & 370 \\
\hline $\begin{array}{l}\text { West } \\
\text { Java }\end{array}$ & 1.009 & 107 & 79 \\
\hline East Java & 872 & 152 & 95 \\
\hline $\begin{array}{l}\text { Central } \\
\text { Java }\end{array}$ & 711 & 101 & 59 \\
\hline $\begin{array}{l}\text { South } \\
\text { Sulawesi }\end{array}$ & 465 & 118 & 37 \\
\hline Banten & 388 & 33 & 41 \\
\hline Others & 2.234 & 440 & 103 \\
\hline TOTAL & 9.771 & 1.391 & 784 \\
\hline
\end{tabular}

Sumber: Kementerian Kesehatan, 29 April 2020

Covid-19 memberikan pengaruh penting terhadap sirkulasi ekonomi global. Wabah Covid-19 merupakan tantangan bagi dunia perdagangan, terhitung industri jasa keuangan perbankan. Berdasarkan fakta kenyataan perbankan Syariah pada Januari 2020, banyaknya perangkat yang terkait dalam kantor Bank Umum Syariah adalah 1.922 cabang yang terpencar di berbagai daerah Indonesia yang didominasi oleh Pulau Jawa. Sejajar dengan wilayah terbanyak ditemukan Covid-19 ialah di pulau Jawa (Statistik Perbankan Syariah, Januari 2020). Dengan ini memperlihatkan bahwa kebanyakan Kantor Bank Syariah berada pada zona merah.

Covid-19 sangat memberikan pengaruh yang cukup besar bagi kinerja manusia. Perlambatan masalah ekonomi merupakan salah satu dari banyaknya masalah yang timbul karena pengaruh dari munculnya covid-19. Perlambatan ekonomi global dan nasional ini tentu menyebabkan turunnya eksistensi perbankan syariah di indonesia. Dengan bertambahnya kasus Covid-19 di indonesia membuat perbankan syariah yang selama ini memiliki peran yang kebijakan hukum dalam pembangunan ekonomi rakyat pada aktivitas ekonomi yang produktif, pada situasi Covid-19 perbankan syariah di tuntut untuk melakukan usaha, memikirkan 
kebijakan hukum baru yang digunakan untuk mengatasi segala macam risiko yang terjadi pada masa Covid-19 dengan cepat dan tepat agar tetap bertahan dalam menghadapi situasi tersebut.

Adapun kebijkan yang dikeluarkan oleh OJK adalah POJK Nomor 18/POJK.03/2020 tentang "Perintah Tertulis Untuk Penanganan Permasalahan Bank" poin b berbunyi "Kewenangan OJK memberikan Perintah Tertulis Kepada Bank untuk: 1. Melakukan penggabungan, peleburan, pengambilalihan, dan/atau integrasi; dan/atau 2. Menerima penggabungan, peleburan, pengambilalihan, dan/atau integrasi.

Bank Syariah Mandiri berlaku pada seluruh daerah sektor ekonomi masyarakat misalnya konsumsi dan investasi. Di masa pandemi COVID-19, bank syariah mandiri sangat dibutuhkan guna memberi sokongan sektor ekonomi yang tengah menjalani keadaan yang baik melampaui penataan struktu kredit konsumen serta melampaui proses pembiayaan kredit baru. Bank syaiah mandiri mempunyai peran yang penting bagi menjalankan ekonomi syariah, yaitu ekonomi yang berfundamen dalam filsafat islam bagi kepentingan umat manusia. mengingat banyaknya pengaruh wabah terhadap perekonomian dan pokok utama peran bank syariah di indonesia maka penyelidikan dapat dikaitkan pada peran bank syariah mandiri bagi perekonomian indonesia di waktu berwabah covid-19 ini penting untuk dilakukan.(Hafizd 2020)

\section{Literature Review}

Penyajian data tentang pengaruh pandemi covid-19 terhadap ekonomi dilakukan oleh sumarni dalam tahun 2020 . Penyajian data ini bertema mengenai "Pandemi COVID-19: tantangan ekonomi dan bisnis" ini menjadi penyebab bagi pandemi COVID-19 yang menimpa indonesia dan menyebabkan pengaruh pada sektor ekonomi. Pernyajian data terebut bertujuan guna mengetahui pengaruh dari covid-19 yang mengetahui pengaruh dari covid-19 yang menjadi tantangan ekonomi dan bisnis syariah pada indonesia dengan menggunakan pendekatan kualitatif. Hasil pemeriksakan menyatakan bahwa ekonomi dan bisnis syariah bisa memberikan donasi bagi warga yang berpengaruh covid-19 dengan mengemukakan terjangkaunya maqashid syariah. (Yenti Sumarni 2020)

Perbankan syariah adalah sektor keuangan yang berpengaruh terhadap wabah yang berkepanjangan. Momen ini sebagai peluang bagi perbankan syariah dan forum-forum keuangan lainnya guna berkontribusi dalam membantu ekonomi warga.(Iskandar, Possumah, and Aqbar 2020a). Dengan ini dibuktikan dengan menimbulkan Peraturan Otoritas Jasa Keuangan (POJK) No.11/POJK.03/2020 mengenai Relaksasi Kredit/Pembiayaan bagi warga yang terpengaruh wabah Covid-19 (OJK, 2020).

Perbankan syariah kegunaanya menjadi forum intermediasi atau mediator keuangan yang mempertemukan antara masyarakat yang kelebihan dana dengan masyarakat yang kekurangan dana, namun disisi lain ancaman terhadap virus covid-19 menjadi tantangan bagi lembaga perbankan.

\section{Metode Penelitian}

Penelitian ini menggunakan penelitian deskriptif kualitatif. Objek penelitian ini ialah Bank Syariah Mandiri yang pilih menggunakan pendapat menjadi salah satu forum jasa keuangan yang menaruh donasi besar dalam perekonomian di indonesia. Tujuan penelitian ini merupakan guna mengetahui dampak wabah terhadap ekonomi indonesia, pengaruh wabah covid-19 terhadap usaha bank syariah mandiri dan kebijakan ojk pada masa wabah covid-19. Peneliti menggunakan hasil penelitian ilmiah guna mencari informasi melalui buku referensi, jurnal ilmiah, situs berita online, dan 
literatur lainnya yang relevan dengan menggunakan tema penyajian data untuk membentuk landasan teori.

\section{Hasil dan Pembahasan}

\subsection{Otoritas Jasa Keuangan (OJK)}

Otoritas Jasa Keuangan merupakan lembaga yang bukan hanya menyandang independen, berdiri sendiri, akan tetapi kewenangannya juga berbeda dengan kewenangan forum sebelumnya yaitu Bank Indonesia yang selama ini tidak mempunyai wewenang dalam melakukan penyidikan, tetapi OJK memilikinya. Selain hal itu, OJK mempunyai wewenang dalam mengambil fee dari forum keuangan yang diawasinya. Fee tersebut akan dipakai menjadi forto forum yang baru lahir. Dalam masa perubahan ini, pada tanggal 1 januari 2013 OJK akan mengawali dengan tugasnya untuk memperhatikan forum keuangan non bank dan baru mulai 1 januari 2014 akan memulai tugas guna memperhatikan perbankan di indonesia. (Hasibuan 2009) (Albanjari and Kurniawan 2020)

\subsection{Bank Syariah}

Bank syariah merupakan bank yang mengedepankan aktivitas bisnisnya menurut prinsip syariah dan dari jenisnya terdiri atas bank umum syariah dan bank pembiayaan rakyat syariah (DPR \& Presiden, 2008). Bank syariah merupakan bank yang menjalankan aktivitas bisnis menurut prinsip syariah, ialah ketentuan perjanjian menurut hukum syariah antara bank dan pihak lain untuk penyempinan dana dan pembiayaan aktivitas bisnis, atau aktivitas lainnya yang dinyatakan sinkron sepadan dengan syariah. (Yumanita n.d.)(Dahlan 2001)

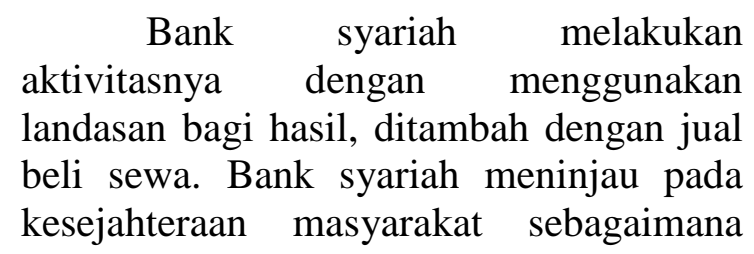

tujuan ekonomi syariah. Bank syariah atau perbankan mempunyai perihal yang terbagi menjadi bank umum syariah (BUS), unit usaha syariah (UUS), danbank perkreditan rakyat syariah (BPR Syariah). Aktivitas perbankan syariah bersangkutan dengan kelembagaan lain di luar bank, yaitu dewan syariah nasional, (DSN), dewan pengawas syariah (DPS), badan arbitrase syariah nasional (BASYARNAS), bank indonesia (BI), dan otoritas jasa keuangan (OJK). (Yumanita n.d.)

\subsection{Ekonomi}

Ekonomi merupakan seluruh kegiatan yang dilakukan bagi manusia dalam usaha memenuhi kebutuhan dan keinginan. Ekonomi adalah faktor krusial bagi setiap manusia, negara berhak mengatur kesejahteraan yang adil bagi seluruh warga negara indonesia. Proses ekonomi dengan baik melalui proses perundang-undangan dengan memberikan kemaslahatan yang besar bagi rakyatnya. Stabilitas dan pertumbuhan ekonomi masyarakat bagi meningkatkan perekonomian negara secara makro. Pertumbuhan ekonomi menjadi faktor yang mendukung pembangunan nasional. Ekonomi berhubungan dengan kebutuhan dan keinginan. Kebutuhan merukan sesuatu yang harus diperoleh dan jika tidak terpenuhi akan menggangu fisik dan psikis manusia, sedangkan keinginan merupakan sesuatu yang bila tidak terpenuhi maka akan menggangu psikis tetapi tidak mengganggu fisik manusia. kebutuhan adalah hal yang diperlukan manusia baik benda ataupun jasa yang bisa memberikan kepuasan serta kemakmuran. (Karim, 2004) (Putong 2010) (Gilarso 2004)

\subsection{Covid-19}

Wabah Coronavirus Disease-19 (COVID- 19) merupakan penyakit atau epidemi yang menyebar berdasarkan suatu daerah ke beberapa negara dan menghipnotis sejumlah besar orang di seluruh global termasuk Indonesia. Virus 
corona menyebar luas di seluruh global dengan cepat. Istilah wabah tidak ada hubungannya dengan keganasan penyakit melainkan lantaran penyebarannya yang meluas. (Hafizd 2020). Virus corona dikenal dengan Corona Virus disease 2019 (Covid-19) awalnya ditemukan di Wuhan China dalam akhir Desember 2019, diduga berasal dari fauna liar kelalawar yang bermutasi berdasarkan fauna pada manusia, juga dari manusia pada manusia. Gejala awal terinfeksi Covid-19 demam, batuk, dan sesak napas. Gejala tinggi sulit bernapas, dada terasa sakit, kepala sakit, badan kaku sulit bergerak, area paras membiru (Nur Fitriatus Shalihah, 2020), sebab akibatnya Covid-19 bisa mematikan yang terinfeksi. Penyebaran Covid-19 pada beberapa Negara semakin meningkat, termasuk pada Indonesia. (García Reyes 2013)(Tedros Adhanom Ghebreyesus, 2020). Pemerintah Indonesia memutuskan Covid-19 menjadi bencana nasional (Kepres 12 tahun 2020) (Yunus and Rezki 2020) (Yenti Sumarni 2020) (Yuliana 2020)

\section{Dampak Pandemi terhadap Perekonomian Indonesia}

Ekonomi merupakan faktor yang terpenting dalam kehidupan manusia. Kebutuhan ekonomi erat kaitannya dalam kehidupan sehari-sehari. (Yamali and Putri 2020a). Pada tahun 2020 ini, banyak kerugian yang ditimbulkan dari wabah ini yang berpengaruh pada perekonomian indonesia. Setelah mengalami peningkatan kasus yang melesat dengan waktu yang sangat cepat, pemerintah membuat kebijakan dalam mengatasi wabah covid-19 dengan berlakunya PSBB yang tercantum dalam peraturan pemerintah No. 21 tahun 2020. (Zulkipli and Muharir 2021) (Iskandar, Possumah, and Aqbar 2020b)

Pengaruh pada sektor ekonomi pada masa wabah covid-19 di Indonesia, antara lain:

a. Terjadinya PHK besar-besaran. hasil data yang didapat yaitu $\geq 1,5$ juta pekerja di rumahkan dan terkena PHK yang mana 90\% pekerja di rumahkan dan pekerja yang di PHK sebesar $10 \%$.

b. Terjadinya penurunan PMI Manufacturing Indonesia mencapai 45,3\% pada Maret 2020. c. Terjadinya punurunan impor sebesar $3,7 \%$ pada triwulan I. d. Terjadinya inflasi yang telah mencapai pada angka $2,96 \%$ year-on-year(yoy) yang telah disumbangkan dari harga emas dan komoditas pangan pada maret 2020 .

e. Terjadinya keterbatalan penerbangan yang mengakibatkan penurunan pendapatan di sector tersebut. Kerugian yang dirasakan mencapai Rp. 207 miliar. Batalnya penerbangan tersebut sebanyak 12.703 pada 15 bandara pada bulan januarimaret 2020. (Yamali and Putri 2020b)

f. Pada 6 ribu hotel telah terjadi penurunan penempatan (okupansi) hingga mencapai $50 \%$. Hal tersebut bisa mengakibatkan kehilangan devisa pariwisata. (Hanoatubun 2020)(Iskandar, Possumah, and Aqbar 2020b)(Arianto 2020).

Mekanisme pasar yang terganggu akibat pengaruhnya covid yang menyelenyapkan surplus ekonomi, namun dampak dari covid-19 ini juga ada pengaruh positifnya terhadap perekonomian Indonesia (Susilo et al. 2020) yaitu akan terbukanya peluang baru pasar ekspor selain China. Dampak positif dari wabah ini merupakan peluang bagi Indonesia untuk dapat memperkuat perekonomian dalam negeri. Hal ini dikarenakan wabah ini mengakibatkan pemerintah akan memprioritaskan serta memperkuat daya beli di dalam Negeri saja. Dengan hal ini, pemerintah bisa memanfaatkan dengan baik agar investasi tetap stabil walaupun pertumbuhan ekonomi yang terjadi saat ini sedang terancam secara global. (Hanoatubun 2020)(Abdi 2020)

Ditengah wabah covid 19 ini, Bank Indonesia akan berusaha mempertahankan perekonomian Indonesia yang sedang tidak

JIEB, Jilid 7, No 2,Juli 2021 ISSN Online 2615-2134 
stabil ini. Perekonomian Indonesia menurun hingga 5\% dengan adanya wabah ini yang suatu saat mungkin akan mengalami penurunan lagi jika pandemik ini terus berlangsung lama. Selain itu, terjadinya secara signifikan pelemahan indeks harga saham dan beberapa perusahaan BUMN mengalami kerugian pada tahun ini. Diperkirakan pertumbuhan ekonomi di Indonesia bisa mencapai 2,5\% jika pandemic covid-19 ini akan berlangsung lama. (Hanoatubun 2020)

\section{Dampak Pandemi terhadap Bank Syariah Mandiri}

Bank Syariah Mandiri merupakan bank yang memadukan semangat idealisme bisnis dengan nilai spiritual di dalam kegiatan operasionalnya. (BSM, 2017). BSM memiliki visi menjadi bank syariah terdepan dan modern. BSM memberikan pesan kepada konsumen bahwa BSM merupakan bank pilihan yang memberikan manfaat, menentramkan dan memakmurkan bagi pegawai, BSM merupakan bank yang menyediakan kesempatan untuk beramanah sekaligus berkariri dengan cara profesional. Untuk investor BSM merupakan institusi keuangan syariah indonesia yang terpercaya yang terus memberikan value kesinambungan.

Dampak pada Manajemen Strategi Bank Syariah Mandiri. Bank Syariah Mandiri selama wabah covid-19 ini mengeluarkan kebijakan terkait dengan produk dan layanan sebagai berikut: pertama, Mandiri Syariah Mobile (MSM) biasa disebut sebagai Superaps, yang mana satu aplikasi tidak hanya dapat melakukan transaksi keuangan tetapi juga menawarkan berbagai fitur tambahan seperti fitur pembayaran zakat, sedekah, wakaf serta ibadah melalui kemudahan dengan mendapatkan jadwal sholat, arah kiblat, lokasi masjid, juz amma, kutipan hadits, dan lain-lain. MSM juga dapat pula untuk transaksi e-commerce, pembayaran haji, top-up e-wallet (emoney, gopay, ovo). Kedua QRIS, Ketiga, Kebijakan stimulus perekonomian Nasional No. 11/POJK.03/2020. Bank memberikan fasilitas pembayaran dan penurunan margin bagi hasil untuk jangka waktu tertentu dan persyaratannya disesuaikan dengan sektor ekonomi, kriteria, dan kondisi nasabah dengan tetap mengacu pada ketentuan ojk untuk nasabah terutama UKM. (Ningsih and Mahfudz 2020)

Akibat Covid-19, terdapat beberapa risiko yang akan dihadapai pada sektor perbankan syariah, antara lain:

1. Risiko pembiayaan, risiko akibat kegagalan nasabah dalam memenuhi kewajiban pada bank sesuai perjanjian yang disepakati diawal. Karena saat pandemi seperti ini, tidak sedikit nasabah bank kehilangan pekerjaan maupun menurunya pendapatan dari usahanya. Sehingga, mereka tidak memiliki penghasilan normal untuk membayar pembiayaan tersebut. Hal ini, berimbas pada perlambatan praktek pembiayaan yang terjadi di bank syariah.

2. Risiko pasar, risiko dimana posisi neraca terjadi perubahan harga pasar yang disebabkan oleh nilai tukar. Pada risiko ini bank syariah tidak mengalami risiko besar, karena bank syariah menggunakan sistem bagi hasil. Jadi neraca pada bank syariah lebih fleksibel mengikuti perubahan bagi hasil dari nasabahnya karena pendapatan yang ikut berubah.

3. Risiko operasional, risiko ini berupa perlambatan operasional seperti pembatasan front office, pembatasan nasabah yang datang ke bank, dan juga pemotongan jam operasional, bahkan ada beberapa penutupan cabang bank syariah di beberapa daerah Dengan adanya 
risiko yang dihadapi akibat dampak Covid-19 tersebut, bank syariah dapat mengubah risiko tersebut menjadi suatu peluang atau tantangan baru untuk meningkatkan market share perbankan syariah. (Albanjari and Kurniawan 2020)

Dampak pandemi pada kegiatan intermediasi BSM dapat dilihat dari perkembangan pembiayaan dan dana pihak ketiga (DPK). Pembiayaan BSM mengalami peningkatan hingga akhir Juni 2020 sejumlah Rp75,61 triliun, meningkat 5,8\% dari Juni 2019 yang sebesar Rp71,47 triliun. DPK pada Juni 2020 sebesar Rp101,78 triliun, mengalami peningkatan $16,52 \%$ dari Rp87,36 triliun per Juni 2019. Berdasarkan total dana tersebut, porsi low cost fund mencapai 57,93\%. Pertumbuhan DPK mampu menambahkan aset Bank Mandiri Syariah pada juni 2020 hingga Rp. 114,40 triliun atau naik 13,26 persen dari juni 2019 yang sebesar Rp. 101,01 triliun. Pencapaian yang diperoleh memperkuat posisi BSM sebagai bank syariah terbesar di Indonesia. Kualitas pembiayaan menjadi tantangan di masa pandemi. BSM mempertebal cadangan likuiditas yang berdampak pada penurunan angka non performing financing (NPF) Net dari 1,21\% per Juni 2019 menjadi 0,88\% per Juni 2020. Sedangkan, NPF Gross turun dari 2,89\% di Juni 2019 menjadi 2,57 \% per Juni 2020 (BSM, 2020). (Setiawan and Indriani 2016)

Laba bersih BSM berhasil diperoleh dari keberhasilan dalam peningkatan pembiayaan dan penghimpunan dana pihak ketiga (DPK). Keberhasilan tersebut mendorong peningkatkan aset dan komposisi low cost fund dan keberhasilan BSM menurunkan angka non performing financing (NPF) diperoleh melalui penyaluran pembiayaan secara selektif dan berkualitas. BSM berhasil membukukan laba bersih sebesar Rp. 719 miliar per juni 2020 naik secara signifikan yaitu $30,52 \%$ dibanding tahun lalu. Kenaikan laba ditopang oleh pendapatan margin dan FBI yang berasal dari layanan digital.

\section{Kebijakan OJK Menghadapi Covid-19}

Pemerintah melalui Otoritas Jasa Keuangan (OJK) mengesahkan beberapa re- gulasi guna memberikan stimulus perekonomian. Regulasi tersebut antara lain: (1) PJOK No. 11/PJOK.03/2020 tanggal 16 maret 2020 tentang stimulus perekonomian nasional sebagai kebijakan Counter cyclical yang berpengaruh dalam penyebaran Coronovirus Disease 2019 (PJOK Stimulus Covid-19), (2) Surat Kepala Eksekutif Pengawas Perbankan No. S-5/D.03/2020 tanggal 19 maret 2020 perihal penyesuaian batas waktu laporan bank (Surat KEPPOJK). (3) PJOK No.18/PJOK.03/2020 tanggal 21 April 2020 tentang Perintah Tertulis Untuk Penanganan Permasalahan Bank (PJOK Perintah Tertulis), (4) Surat Kepala Eksekutif Pengawas Perbankan No.S8/D.03/2020 tanggal 30 April 2020 perihal Penerapan ISAK 102, PSAK 110, dan PSAK 68 dalam Kondisi Pandemi Covid19 (Surat KEPP OJK).

\section{PJOK Stimulasi Covid-19}

Target Lembaga Jasa Keuangan dari PJOK Stimulus Covid-19 berlaku bagi BUK, BUS, UUS, BPR, dan BPRS. Sedangkan target debitur (termasuk UMKM) yang mengalami kesulitan likuiditas untuk memenuhi kewajiban pada Bank karena debitur atau usaha debitur terdampak dari penyebaran Covid-19 baik secara langsung maupun tidak langsung pada sektor ekonomi, yaitu pariwisata, transportasi, perhotelan, perdagangan, pengelohan, pertanian, dan pertambangan.

Sebagai contoh debitur yang terkena dampak penutupan jalur transportasi dan pariwisata dari dan ke Tiongkok atau Negara lain yang telah 
terdampak Covid-19 serta travel warning beberapa negara. Debitur yang terkena dampak dari penu- runan volume ekspor impor secara signifikan akibat keterkaitan rantai suplay dan perdagangan dengan Tiongkok atau- pun negara lain yang terdampak Covid- 19. Debitur yang terkena dampak terhambatnya proyek pembangunan infrastruktur karena terhentinya pasokan bahan baku, tenaga kerja, dan mesin dari tiongkok ataupun negara lain yang telah berpengaruh pada covid-19. Berikut penulis telah merangkum PJOK Stimulus Covid-19 BUS/UUS dan PJOK Stimulus Covid-19 BPRS. (Gojali n.d.)

\section{Kebijakan OJK dalam Menghadapi Resesi Covid-19}

Pertama, perbankan harus mampu mengidentifikasi dampak covid-19 terhadap sektor rill, pertumbuhan ekonomi, kinerja konsumen pembiayaan dan aspek lainnya yang memengaruhi kesehatan perbankan. Kemudian, perbankan juga harus menyusun berbagai skenario dampak Covid 19 terhadap perekonomian dan efek rembetan pada kinerja perbankan. Kedua, perbankan harus memitigasi risiko kredit dan kecukupan likuiditas. Hal tersebut dapat dilakukan dengan memahami sektor ekonomi dan konsumen pembiayaan berpengaruh beserta kinerjanya. Perbankan juga harus mengaktifkan sistem peringatan dini dan menyusun skenario restrukturisasi serta upaya penyelamatan nasabah pembiayaan. Ketiga, perbankan harus melaksanakan stress test kecukupan modal dan likuiditas. Sehingga, perbankan perlu melakukan analisis skenario terhadap kebutuhan dan ketersediaan modal terkait dengan peningkatan risiko kredit. Kemudian, perlu dilakukan identifikasi GAP likuiditas dan uji berbagai strategi tersebut. Keempat, perbankan juga harus mengoptimalisasi pengelolaan portfolio dengan mengidentifikasi portfofolio yang rentan terpengaruh dan terdampak. Kemudian, perbankan juga harus optimalisasi alokasi modal dan ketersediaan likuiditas dan terapkan berbagai skenario krisis. (Kumbure et al. 2020).

\section{Kesimpulan}

Berdasarkan hasil studi dapat disimpulkan bahwa pandemi COVID-19 berdampak pada sektor ekonomi yang tercermin dari penurunan pertumbuhan ekonomi dan bisnis khususnya sektor investasi, perdagangan, transportasi, dan pariwisata. Kegiatan intermediasi Bank Syariah Mandiri mengalami peningkatan positif dan berhasil menyumbangkan laba. Peran Bank Syariah Mandiri terhadap ekonomi di masa pandemi meliputi restrukturisasi pembiayaan nasabah yang terdampak pandemi COVID-19, pembagian bantuan sosial, pemaksimalan program corporate social responsibility (CSR), menjaga protokol kesehatan dan pengalihan kegiatan bank menjadi berbasis digital.

Berbagai macam kebijakan telah dibuat dibuat oleh pemerintah Indonesia dalam menangani pandemic covid-19 yang sedang marak terjadi. Kebijakan yang ada tersebut secara langsung berdampak positive namun secara tidak langsung juga dapat menimbulkan dampak negative, salah satunya yang dapat kita ketahui saat ini yaitu merosotnya pertumbuhan ekonomi di Indonesia. Dampak pada sector ekonomi di Indonesia akibat dari pandemic ini antara lain terjadinya PHK, terjadinya PMI Manufacturing Indonesia, penurunan impor, peningkatan harga (inflasi) serta terjadi juga.

Otoritas Jasa Keuangan (OJK) menerbitkan POJK No.11/PJOK.03/2020 untuk memberikan relaksai pada nasabah perbankan, termasuk perbankan syariah didalamnya yaitu kemudahan proses restructuring dan rescheduling untuk nasabah yang terkena dampak Covid-19, khususnya nasabah usaha mikro, kecil, dan menengah (UMKM). Akibat Covid-19, 
terdapat beberapa risiko yang akan dihadapai pada sektor perbankan syariah, antara lain risiko pembiayaan, risiko pasar, dan risiko operasional. Dengan adanya risiko yang dihadapi akibat dampak Covid19 tersebut, bank syariah dapat mengubah risiko tersebut menjadi suatu peluang atau tantangan baru untuk meningkatkan market share perbankan syariah.

\section{DAFTAR PUSTAKA}

Abdi, Muhammad Nur. 2020. "Krisis Ekonomi Global Dari Dampak Penyebaran Virus Corona (Covid19)." AkMen Jurnal Ilmiah 17(1): 9098.

Albanjari, Fatkhur Rohman, and Catur Kurniawan. 2020. "Jurnal Eksyar ( Jurnal Ekonomi Syariah )." Jurnal Eksyar (Jurnal Ekonomi Syariah) 07(01): 24-36.

Arianto, Bambang. 2020. "Dampak Pandemi COVID-19 Terhadap Perekonomian Dunia." JURNAL EKONOMI PERJUANGAN 2(2).

Dahlan, Siamat. 2001. "Manajemen Lembaga Keuangan Lainnya."

Djalante, Riyanti et al. 2020. "Review and Analysis of Current Responses to COVID-19 in Indonesia: Period of January to March 2020." Progress in Disaster Science 6: 100091.

García Reyes, Luis Enrique. 2013. "OTORITAS JASA KEUANGAN." Journal of Chemical Information and Modeling 53(9): 1689-99.

Gilarso, T. 2004. Pengantar Ilmu Ekonomi Makro. Kanisius.

Gojali, Arifin. "Penerapan Akuntansi Murabahah Di Tengah Pandemi Covid-19 Dan Kebijakan Stimulasi Perekonomian Nasional."

Hafizd, Jefik Zulfikar. 2020. "Peran Bank
Syariah Mandiri (Bsm) Di Masa Pandemi Covid-19." Al-Mustashfa: Jurnal Penelitian Hukum Ekonomi Syariah 5(2): 138.

Hanoatubun, Silpa. 2020. "Dampak Covid19 Terhadap Prekonomian Indonesia." EduPsyCouns: Journal of Education, Psychology and Counseling 2(1): 146-53.

Hasibuan, Malayu S P. 2009. "Dasar-Dasar Perbankan.” Jakarta: Bumi Aksara.

Hidayat, Sutan Emir, Mohammad Omar Farooq, Atiqoh Nasution, and Citra Atrina Sari. 2020. The Impact Of COVID-19 Outbreak On The Islamic Finance In The OIC Countries COVID-19 And Its Impacts On The Islamic Financial Industry In The OIC Countries.

Iskandar, Azwar, Bayu Taufiq Possumah, and Aqbar. 2020a. "Peran Ekonomi Dan Keuangan Sosial Islam Saat Pandemi Covid-19." SALAM: Jurnal Sosial dan Budaya Syar-i 7(7).

Iskandar, Azwar, Bayu Taufiq Possumah, and Khaerul Aqbar. 2020b. "Peran Ekonomi Dan Keuangan Sosial Islam Saat Pandemi Covid-19." Jurnal Sosial \& Budaya Syar'i FSH UIN Syarif Hidayatullah Jakarta 7(7): 625-38.

Kumbure, Mahinda Mailagaha et al. 2020. "Relation between Managerial Cognition and Industrial Performance: An Assessment with Strategic Cognitive Maps Using Fuzzy-Set Qualitative Comparative Analysis." Journal of Business Research 114: 160-72.

Ningsih, Mardhiyatur Rosita, and Muhammad Syarqim Mahfudz. 2020. "Dampak Pandemi Covid-19 Terhadap Manajemen Industri Perbankan Syariah: Analisis 
Komparatif." Point 2(1): 1-10.

Putong, Iskandar. 2010. "Economics Pengantar Mikro Dan Makro.” : 1-31.

Riduwan, Riduwan, and Rofiul Wahyudi. 2018. "Contribution of Macroprudensial Policy of Central Bank on Microprudensial Islamic Banking." INFERENSI: Jurnal Penelitian Sosial Keagamaan 11(2): 291-308.

Setiawan, Ulin Nuha Aji, and Astiwi Indriani. 2016. "Pengaruh Dana Pihak Ketiga (DPK), Capital Adequacy Ratio (CAR), Dan Non Performing Financing (NPF) Terhadap Profitabilitas Bank Syariah Dengan Pembiayaan Sebagai Variabel Intervening." Diponegoro Journal of Management 5(4): 1-11.

Susilo, Adityo et al. 2020. "Coronavirus Disease 2019: Tinjauan Literatur Terkini." Jurnal Penyakit Dalam Indonesia 7(1): 45-67.

Wahyudi, Rofiul, Siti Mujibatun, and Riduwan Riduwan. 2019. "Debt And Equity-Based Financing, Size And Islamic Banks Profitability: Empirical Evidence From Indonesia." Iqtishadia 12(2): 227.

Yamali, Fakhrul Rozi, and Ririn Noviyanti Putri. 2020a. "Dampak Covid-19 Terhadap Ekonomi Indonesia." Ekonomis: Journal of Economics and Business 4(2): 384.

Terhadap 2020b. "Dampak Covid-19 Ekonomis: Journal of Economics and Business 4(2): 384-88.

Yenti Sumarni. 2020. "Pandemi Covid-19: Tantangan Ekonomi Dan Bisnis." Jurnal Ekonomi dan Perbankan Syariah 6(2): 46-58.

Yuliana, Yuliana. 2020. "Corona Virus
Diseases (Covid-19): Sebuah Tinjauan Literatur." Wellness And Healthy Magazine 2(1): 187-92.

Yumanita, Diana. "Bank Syariah: Gambaran Umum.”

Yunus, Nur Rohim, and Annissa Rezki. 2020. "Kebijakan Pemberlakuan Lock down Sebagai Antisipasi Penyebaran Corona Virus Covid-19." Salam: Jurnal Sosial dan Budaya Syar-i 7(3): 227-38.

Zulkipli, Zulkipli, and Muharir Muharir. 2021. "DAMPAK COVID-19 TERHADAP PEREKONOMIAN INDONESIA." JIMESHA: Jurnal Ilmiah Mahasiswa Ekonomi Syariah 1(1): 7-12. 